\title{
The 2011 Commonwealth Local Government Conference - Energising Local Economies: An Overview
}

\author{
Commonwealth Journal of Local Governance \\ Issue 8/9: May-November 2011 \\ http://epress.lib.uts.edu.au/ojs/index.php/cjlg
}

\author{
Sue Rhodes \\ Commonwealth Local Government Forum
}

"The theme of your conference, Energising local economies: partnerships for prosperous communities, is highly relevant at this time of global economic downturn. The Commonwealth with its connections, economic success, and commitment to free trade and democracy, has the potential to contribute significantly to the prosperity of all its members. Local democracy, as promoted by the Commonwealth Local Government Forum, is a key component of the core Commonwealth values, responding to the needs of local communities, and working with a range of partners to deliver quality public services, often with limited resources."

Rt Hon David Cameron, Prime Minister of the UK, in his message to the conference

In the current economic climate, creating the right environment for local enterprise, inward investment, and business and skills development, is an important factor in ensuring the prosperity and wellbeing of local communities. The impact of the global financial crisis has not been uniform across the Commonwealth and countries are using different strategies to overcome their financial difficulties. Local government increasingly plays an important part in this. More and more local governments in countries across the Commonwealth have responsibilities and powers for local economic development: in some countries local authorities can already show how their policies and actions are helping energise their local economies, while in other countries local councils are just beginning to get to grips with these responsibilities. ${ }^{1}$

\footnotetext{
1 The conference background paper, Energising local economies: local economic development around the Commonwealth by Prof. P. S. Reddy and Malcolm Wallis, and Energising local economies: partnerships for prosperous
} 
There is general agreement that the role of local government must go beyond traditional service delivery and seek to provide the leadership needed to energise local economies and communities. Localities globally have a critical role in investment, decision-making and development as has been acknowledged by the UN-Habitat and the World Bank in the recent State of World Cities report. So this year's Commonwealth Local Government Conference - Energising local economies: Partnerships for prosperous communities focusing on local economic development was very timely. LED not only can help reduce poverty and deliver the MDGs, but creates a climate for partnership and inward investment that is vital to all communities to improve the quality of life of the people who live there.

\section{What is LED?}

Local economic development (LED) has been in existence and practiced internationally for more than three decades. LED is a process which brings together different partners in a local area to work together and harness local resources for sustainable economic growth. The World Bank defined LED as:

the process by which public, business and non-governmental sector partners work collectively to create better conditions for economic growth and employment generation. The aim is to improve the quality of life for all.

According to the International Labour organisation LED is:
a participatory process which encourages social dialogue and public/private partnerships in a geographical area. LED enables local stakeholders to jointly design and implement a development strategy which fully exploits local resources and capacities and makes best use of the area's comparative advantages.

Local government has both a leading and enabling role in LED - bringing together all the relevant stakeholders to drive forward the local economy and using its powers and responsibilities to create a positive climate for inward investment and skills development. Local authorities have a wide range of regulatory powers and processes that have an impact on business - such as business taxes and charges, licensing, incentives, procurement policies and land use, and the provision of effective services and modern infrastructure.

communities, conference report are available from the CLGF or can be downloaded from the conference website www.clgc2011.org 
LED is critical for job creation, broadening the local tax base, improving municipal services, and for capacity and institutional development. It is an important mechanism for poverty alleviation. Pro-poor and inclusive LED enables local governments to address poverty, unemployment and social deprivation, including through strategies to promote youth employment, empower disadvantaged and marginalised communities, support skills development, and promote gender equity and equality.

\section{Delivering LED}

There is no blueprint for LED that will be appropriate for every locality; each area has its own opportunities and challenges, natural assets and human resources. For example, the conference heard about the challenges facing the Pacific countries, where natural events such as typhoons and earthquakes are frequent and increasing as a result of climate change, and scarcity of natural resources is compounded with distance to international markets. Thus, for policy transfer to be successful, we must take account of local economic, social and political context.

However, there are common aspects to delivering LED that were generally agreed by delegates at the conference and can be used as a starting point in planning local economic strategies. Delegates identified a number of key actions for local government if it is to play its full role in local economic development: having a clear national framework, an enabling environment, good local strategy development, partnership working with the private sector and others, adequate resources, and the ability to adapt to changing local, national and international circumstances.

There was strong agreement that local government is the key player and has a leading role, but must work in partnership with other stakeholders, including the private sector, civil society and, importantly, other levels of government including national governments. Local government cannot do it all by itself. There has to be firm commitment and support from all the major stakeholders.

Although Trinidad and Tobago has an economy based on oil, as a small nation it has many economic challenges as Mayor Orlando Nagessar, Chairman of the Trinidad and Tobago Association of Local Government Authorities, explained. He said that local authorities in his country are developing strategies and approaches to LED and poverty reduction that best suit their localities, and involving communities to make them 
participants in the economic life of the community. He explained that in the current financial climate it is critical to look at solutions that can be implemented at little or no cost. As a result, every local authority has developed a local economic plan in consultation with stakeholders which is dependent on local partnerships. These include strategies to attract investors, especially for the tourist industry and business development.

Having a clear national framework is helpful in ensuring that national and local government efforts are coordinated and complement each other. One of the conference workshops discussed a pilot project in Uganda which has been developed by the UNCDF with the government. This aims to achieve a whole of government response to LED and has helped to review the national framework as well as supporting local governments to boost their capacity. LED is now a clear and key component of the development plans which local authorities must prepare.

In her address to the conference Hon Kamla Persad-Bissessar, Prime Minister of Trinidad and Tobago and Chairperson-in-Office of the Commonwealth, emphasised that "Energising local economies and creating partnerships for prosperous communities requires a fundamental shift in philosophy for governance, particularly at central level".

Capacity and financial resources continue to be a problem, and often there is a gap between expectations and resources. According to the conference statement: "the underfunding of local government to deliver its statutory series often results in inability to deliver effective LED. Effective decentralisation and guaranteed and innovative funding sources are essential for local government to support LED." Local government not only needs funding to be decentralised along with its responsibilities, but must also develop the capacity and expertise to be able to use innovative financing mechanisms and access credit.

In Tanzania, the government's National Economic Empowerment Policy (NEEP) has provided a framework for economic development and is increasing the level of citizen participation in economic activities. The NEEP has enabled better access to credit, soft loans, and direct loans, including local government community development funds for young people and women economic groups. Local governments are further supporting community-led skills and other forms of development through specific funds in villages 
and poor communities and have provided employment opportunities in public works programmes that increase local incomes and skills.

LED needs to address poverty and disadvantage, and empower disadvantaged and marginalised communities. Rwanda's Minister of Local Government, Hon. Jamea Musoni explained how reforms in Rwanda have been recognised by the World Bank. Though there are still many challenges to be overcome, LED has become a major focus for local government as part of a process of decentralisation, and local economic projects and investment have been boosted through local savings and credit cooperatives and micro finance projects to support women.

For local economies to continue to thrive and grow, local governments must be able to adapt to rapid change and to local, national and international markets. Strategies must be continually reviewed and updated to take into account the changing economic, social and political environment. Cardiff Council demonstrated how it has used tourism, sports and major events to transform the city, following the decline of heavy industries. It has refocused the local economy, creating a sport infrastructure which it has used to drive regeneration and brought in key events to attract inward investment. Council representatives emphasised the need for buy-in from residents and ensuring that benefits are spread across the city, particularly some of the more economically disadvantaged communities. It has done this by bringing together service and skills agencies to make sure that the local labour force can provide the skilled workforce needed by new investors.

Technology can bring a leap into the future to enable countries to compete for jobs and services. The Deputy Commissioner of Ahmedabad, India, Mr I K Patel, described how the city has invested in infrastructure and people, constantly upgrading skills to be at the cutting edge of technology. As a result, Ahmedabad now has one of the highest per capita incomes in India.

\section{Conference Recommendations}


In the conference statement - the Cardiff consensus for local economic developmentdelegates agreed on a number of actions to enable local government to play its full role in LED.

They declared that 'Ministries of local government play a key facilitation and coordination role in this process, and in assessing and monitoring the impact of LED' and they called on national and state/provincial governments to "establish national LED frameworks, and ensure decentralisation of appropriate powers, functions and resources, including financial resources, empowering local government to play a leading role in LED'.

They agreed that local governments should plan, develop and implement LED strategies in partnership with the private sector and other stakeholders at the local level and develop a strong alliance with the private sector to ensure that LED promotion and actions are well-grounded.

Participants also agreed that local government associations play a key role in advocating for local government involvement in LED, operationalising national frameworks and assessing impact. They are important partners in sharing good practice, capacity development and identifying and leveraging resources for LED.

In addition the delegates called on the CLGF to advocate for LED to be a key responsibility for local government across the Commonwealth, and to advocate for LED within the wider Commonwealth, to generate better understanding and support for local government's role in LED and to share good practice and knowledge about LED, through its various networks.

Finally, they called on development partners to provide resources, support and expertise to improve capacity and enable local governments to deliver effective LED, and emphasised the importance of development partners making funding available directly to local governments.

\section{Next Steps}


Commonwealth Heads of Government endorsed the Cardiff Consensus at their meeting in Perth at the end of October 2011. They "supported and upheld the role of local government in promoting strategies for localism, sustainable development and economic growth," and supported the implementation of the Cardiff Consensus for Local Economic Development. This backing of national governments is essential for CLGF and its member ministries and local governments when they begin to take the recommendations forwards to implement them in their own countries. Ghana has already made reference to the outcomes of the conference in its own national framework for LED which the government recently agreed.

LED is clearly a priority area for our members. CLGF has been working with a number of local authorities in South Africa, Ghana and Jamaica to help them develop local economic development strategies as part of the Commonwealth Local Government Good Practice Scheme and is currently disseminating the lessons and the good practice learned, including developing a toolkit for local authorities in Ghana. Building on this practical work and the policies developed at the conference, we will be looking at how we can develop a programme of support to help local authorities implement LED strategies and working with governments to encourage them to provide the framework and financing to enable this.

However, as Cardiff Council Leader Cllr Rodney Berman said at the closing of the conference: "The real success of the conference can only be measured by the results of the actions that follow from it, leading to a positive impact on our local communities". 